Review

\title{
ADVANCES IN Agrobacterium-MEDIATED PLANT TRANSFORMATION WITH ENPHASYS ON SOYBEAN
}

\author{
Paulo Celso de Mello-Farias; Ana Lúcia Soares Chaves* \\ UFPEL/Instituto de Química e Geociências - Depto. de Bioquímica, C.P. 354 - 96010-900 - Pelotas, RS - Brasil. \\ *Corresponding author<alschaves@yahoo.com.br>
}

\begin{abstract}
Soybean is one of humanity's major sources of plant protein. It is also very important for animal feed and as industrial raw material. Great advances have recently been achieved in its genetic transformation. This review provides a comprehensive discussion of important factors affecting Agrobacterium-mediated soybean transformation including target tissues, plant tissue health, wounding methods, regeneration systems, selectable markers and reporter genes.

Key words: Glycine max, embryogenic tissue, sonication assisted Agrobacterium-mediated transformation (SAAT), green fluorescent protein (GFP)
\end{abstract}

\section{AVANÇOS NATRANSFORMAÇÃO GENÉTICADE PLANTAS MEDIADA POR Agrobacterium COM ÊNFASE EM SOJA}

\begin{abstract}
RESUMO: A soja é uma das maiores fontes de proteína vegetal da humanidade. É também muito importante na alimentação animal e como matéria-prima industrial. Grandes avanços foram recentemente alcançados em sua transformação genética. O objetivo desta revisão é fornecer uma discussão acerca de importantes fatores que influenciam a transformação de soja mediada por Agrobaterium, incluindo tecidos alvo, condições do tecido vegetal, métodos de injúria, sistemas de regeneração, marcadores de seleção e genes repórter.

Palavras-chave: Glycine max, tecido embriogênico, transformação mediada por Agrobacterium por sonicação assistida (SAAT), proteína verde fluorescente
\end{abstract}

\section{INTRODUCTION}

Soybean [Glycine max (L.)Merrill.] has been widely used as human and animal food, as well as an industrial raw material. This species has been modified through biotechnology means. Soybean is used in animal feed, industrial and cooking oils, plastics, adhesives, as well as in a variety of items of processed food. With the aid of biotechnology, plant breeders will be able to produce new varieties with novel traits and disease resistance genes, providing new markets for farmers and reduced chemical use in its cultivation. Soybean varieties improved through biotechnology have been available to farmers. The cropped area in the United States of biotech crops in 2005 was almost 50 million ha (James, 2005). The global area of biotech crops increased more than 50 fold during the ten-year period from 1996 to 2005, from 1.7 million ha in 1996 to 90.0 million ha in 2005 . This rate is one of the highest rates of crop technology adoption in agriculture and reflects the growing acceptance of biotech crops by farmers in both industrial and developing countries. The number of countries growing biotech crops tripled during the same nine-year period, increasing from six in 1996 to nine in 1998, to 12 countries in 1999, and to 21 in 2005 (James, 2005).

Herbicide tolerant soybean continued to be the dominant biotech crop in 2005, occupying 54.4 Mha, and representing $60 \%$ of the global biotech crop area of 90.0 Mha for all crops. It was grown commercially in the USA, Argentina, Brazil, Paraguay, Canada, Uruguay, Romania, South Africa, and Mexico (James, 2005).

To accomplish the potential of biotechnology, efficient methods must exist for gene introduction, resulting in controlled levels of gene expression. Several methods currently exist for introducing foreign DNA into plant cells. Transformation systems based on the bacterium Agrobacterium tumefaciens and on particle bombardment have both been commonly applied to generate transgenic soybean plants (Hinchee et al., 1988). The advantages of Agrobacterium-meditated transformation include the fact that the protocol is relatively straightforward, with minimal equipment costs, and that it results in the insertion of a single or low copy of the transgene (Hansen \& Wright, 1999). 
Transgenic soybean plants have been produced by Agrobacterium-meditated T-DNA delivery into cotyledonary nodes (Hinchee et al., 1988), immature cotyledons (Parrott et al., 1994), and embryogenic suspension cultures (Trick \& Finer, 1998). This method is genotype dependent in terms of susceptibility to Agrobacterium tumefaciens infection, and also on the plant regeneration response (Owens \& Cress, 1985; Hinchee et al., 1988; Delzer et al., 1990). Furthermore, it requires considerable skill to achieve infection of target tissue cells with Agrobacterium (Zhang et al., 1999).

Direct transfer methods for plant transformation rely entirely on physical or chemical principles to deliver DNA into the plant cell. Several different direct DNA transfer methods have been described, including particle bombardment (Klein et al., 1987; Christou et al., 1992), microinjection (Crossway et al., 1986), transformation of protoplasts mediated by polyethylene glycol or calcium phosphate (Negrutiu et al., 1987; Datta et al., 1990), electroporation (Shillito et al., 1985; Fromm et al., 1986) and transformation using silicon carbide whiskers (Frame et al., 1994). Particle bombardment-meditated transformation is more commonly used to achieve transformation of many soybean tissues including shoot meristems (McCabe et al., 1988; Aragão et al., 2000) and embryogenic suspension cultures (Finer \& McMullen, 1991) without the host-range limitation associated with Agrobacterium. This approach, however, tends to result in the integration of large complexes or fragments of transgenes that sometimes leads to gene silencing (Vaucheret et al., 1998; Dai et al., 2001).

Although various methods for DNA introduction exist, particle bombardment and Agrobacteriummediated transformation are the two most widely and effectively used methods. They rely on different modes of DNA transfer (physical versus biological) and the efficiency of each system varies according to species and tissue type. Particle bombardment is the most convenient method for multiple gene transfer to plants since DNA mixtures comprising any number of different transformation constructs can be used, with no need for complex cloning strategies, multiple Agrobacterium strains or sequential crossing. Many studies describe successful integration of two or three different transgenes, in addition to the selectable marker, into plants by particle bombardment, and the maximum reported to date is 13 (Altpeter et al., 2005). Agrobacterium-mediated transformation usually results in fewer copies of the introduced gene and gene expression problems are often reduced (Gelvin, 2003).

\section{CHOOSING THE TARGET}

Soybean is a dicotyledonous plant and a host for Agrobacterium, but this species has proven difficult to transform with this biological vector (Larkin, 2001). Specific plant-bacteria interactions must take place for the transformation to be successful, because DNA must be introduced into cells, which are both susceptible to Agrobacterium and responsive to plant regeneration (Finer, 1988; Rakoczy-Trojanowska, 2002; Gelvin, 2003). Tissue type, age, genotype, and susceptibility to Agrobacterium, all play a role in the effectiveness of bacterial infection. Various tissue types have been used for transformation, but shoot-forming and embryogenic tissues are the most widely used.

Somatic embryogenesis is the development from somatic cells of structures that resemble zygotic embryos, through an orderly series of characteristic morphological stages. Somatic embryos are typically induced from immature zygotic embryos following the addition of the auxin, 2, 4-dichlorophenoxyacetic acid (2, 4-D). Steward et al. (1958) originally reported the induction of somatic embryos from liquid cell cultures of wild carrot. The range of species that can now be regenerated through somatic embryogenesis is very extensive and the process of somatic embryogenesis is used in both basic and applied plant biology research.

Usually somatic embryos are utilized as a model to study zygotic embryogenesis (Zimmerman, 1993), to analyze embryo morphology (Jasik et al., 1995) and to better understand gene regulation during embryo development (Misra, 1994). In the area of cell biology, somatic embryos are used to better understand how cellular mechanisms are regulated during plant development (Corre et al., 1996; Fowke $\&$ Attree, 1996). In the field of molecular genetics, somatic embryogenesis has been used as an integral step for the recovery of transgenic plants (Finer \& Nagasawa, 1988; Nandadeva et al., 1999; Trick \& Finer, 1999; Daniell et al., 2005) and as a tool to better understand the regulation of expression of developmentally-regulated genes during early stages of plant development (Zimmerman, 1993; Patnaik \& Khurana, 2001).

Induction of somatic embryogenesis from immature zygotic embryos of soybean was first reported by Christianson et al. (1983) and different systems for soybean somatic embryogenesis have subsequently been developed (Finer \& Nagasawa, 1988; Bailey et al., 1993; Santarém et al., 1997; Santos et al., 1997; Schmidt et al., 2005). Although several methods for soybean transformation exist, somatic embryos are the most widely used and suitable target tissue for transformation using either particle bombardment (Finer \& McMullen, 1991; Sato et al., 1993; 
Hadi et al., 1996; Hazel et al., 1998; Ponappa et al., 1999) or Agrobacterium-mediated transformation (Trick \& Finer, 1998).

There have been several reports about Agrobacterium-mediated transformation of soybean in the past 15 years mentioning the use of other target tissues. The first report of transformed soybean was made by Hinchee et al. (1988) who used cotyledonary nodes of the cultivar "Peking" as the explant source. For this "cot node" system, cotyledons were inoculated with Agrobacterium and induced to form shoots on tissue culture medium supplemented with benzyl adenine (BA). Six percent of the regenerated plants tested positive for the introduced DNA. This study confirmed that soybean transformation is possible using a susceptible and regenerable cultivar (Finer et al., 1996a).

Even though the cot node system appears to be a good method for Agrobacterium-mediated transformation, problems still exist concerning chimeras. Because the meristematic target tissue is multicellular and subepidermal, the meristem is difficult to be reached and transformation often results in chimeras. The basic concept of the cot node system is to transform a single cell, proliferate that cell, and induce new shoots from this tissue (Finer et al., 1996a). Sectors or chimeras form when the transformed cell does not proliferate adequately and the meristem consists of a mixture of nontransformed and transformed cells.

There have been several other reports of soybean transformation with the cot node system (Zhang et al. 1999; Clemente et al., 2000; Olhoft et al., 2003). Meurer et al. (1998) also reported sectoring using the cot node system. In their study, various Agrobacterium strains and soybean cultivars were evaluated for increased transformation efficiency. Only $1-2 \%$ of recovered shoots were either entirely transformed or chimerical, and no transgenic plants were regenerated. Before the cot node system can be classified as an efficient method of transformation, a more effective method for targeting meristematic cells must be developed and chimerism must be reduced.

In addition to the cot node system of transformation, germinating seeds also have been used as target tissue for Agrobacterium. Chee et al. (1989) used a needle to inoculate the plumule, cotyledonary node, and adjacent cotyledonary tissue with Agrobacterium. Only $0.7 \%$ of the inoculated seeds yielded transformed tissues. This system is extremely inefficient but has the advantage of avoiding tissue culture manipulations that often prove problematic for many soybean cultivars. In another study, Parrott et al. (1989) used immature cotyledons as the target tissue for Agrobacterium-mediated transformation. Cotyledons were inoculated with Agrobacterium and placed on an embryo induction medium followed by transfer to a regeneration medium. This method differs from de cot node system in that plants were regenerated from somatic embryos rather than from shoots. Three transgenic plants were regenerated, however progeny did not contain the introduced DNA, indicating that the primary transformants could be chimeric. Chimeric, primary transformants probably resulted from the subepidermal and multicellular origin of primary somatic embryos (Parrott et al., 1989). Although a transformed, intact plant can be obtained using this method, there is possibly a more suitable target tissue for gene introduction via Agrobacterium.

Recently, an improved cotyledonary node method using an alternative explant for Agrobacteriummediated soybean transformation was reported. The term "half-seed" was used to refer to this alternative cotyledonary explant that is derived from mature seed of soybean following an overnight soaking. Transformation efficiencies ranged between 1.4 and $8.7 \%$ with an overall efficiency of $3.8 \%$. The half-seed system was reported as simple and does not require deliberate wounding of explants, which is a critical and technically demanding step in the cotyledonary node method (Paz et al., 2005).

\section{TRANSFORMATION USING AGROBACTERIUM- MEDIATED SYSTEM}

Agrobacterium tumefaciens is a soil-borne plant pathogen that has been modified for use as a biological vector for plant transformation. Agrobacteriummediated system, this unique transformation method, was reported twenty years ago for introducing genes into plant cells (Horsch et al., 1985) and has continued to be the most commonly-used method for DNA introduction into plants. Agrobacterium tumefaciens has the ability to transfer a portion of its DNA, known as T-DNA, to the genome of the plant (Sheng \& Citovsky, 1996). In nature, the bacterium causes the crown gall disease on dicotyledonous plants. Modified Agrobacterium strains have been developed that do not induce tumor formation, and these strains can carry genes of interest for the purpose of plant transformation (Zambryski, 1988). Since the genes required for the transfer process are not within the T-DNA, any gene of interest can be placed between the 25 base pair sequences that flank the T-DNA. This feature makes Agrobacterium an excellent candidate for manipulating plant genomes (Tinland, 1996). Gene introduction using Agrobacterium is now the most popular method of transformation (Riva et al., 1998; Gelvin, 2003) and has the potential to alter the traits manipulated in plant breeding programs. 
Agrobacterium-mediated transformation has several advantages over other methods of gene introduction. The use of Agrobacterium is less labor intensive, does not require sophisticated equipment, and is more cost effective. Agrobacterium-mediated transformation typically results in a low copy number of the introduced gene, whereas particle bombardment often leads to the introduction of multiple copies (Hadi et al., 1996). Even where multiple copies are present, the adage that higher copy numbers correspond to lower expression levels does not stand up to close scrutiny. Experiences with rice, potato and wheat suggest that higher transgene copy numbers correspond to higher expression levels, indicating that the transgenes were expressed efficiently (Altpeter et al., 2005).

Although being a dicotyledonous plant and a host for Agrobacterium, soybean has proven difficult for Agrobacterium-mediated transformation. Limited success has been reported with Agrobacterium-mediated transformation of seeds, somatic embryos, colyledonary nodes, and immature zygotic cotyledons (Hinchee et al., 1988; Chee et al., 1989; Parrott, et al. 1989; Townsend \& Thomas, 1993; Meurer, 1998; Yan et al., 2000; Gelvin, 2003).

Plant tissue and Agrobacterium must be compatible so that for the process of T-DNA transfer and integration occurs. In addition, DNA must be introduced into cells which are both susceptible to Agrobacterium and responsive to plant regeneration (Finer, 1996b). Tissue type, age, genotype, and susceptibility to Agrobacterium all play a role in the effectiveness of bacterial infection. In addition to the specific plant-bacteria interactions the T-DNA transfer process is controlled by virulence or vir genes. Induction of vir genes is dependent upon various factors which include the presence of phenolic compounds, media $\mathrm{pH}$, and temperature (Statchel et al., 1985; Godwin et al., 1991; Townsend \& Thomas, 1993; Sheng \& Citovsky, 1996). Without phenolic signal molecules to initiate the expression of vir genes, the TDNA transfer process does not occur. Wounded plant tissues produce phenolic compounds such as acetosyringone, which is a signaling molecule for the induction of vir genes (Statchel et al. 1985; Sheng \& Citovsky, 1996). However, some soybean genotypes may not produce enough acetosyringone to induce the vir genes (Godwin et al., 1991); therefore to enhance DNA transfer, the tissue culture media can be supplemented with this compound. Other options for enhancing transformation include using mutant bacteria that constitutively express their vir genes (Hansen et al., 1994). Induction of vir genes is simply another factor, which can influence the efficiency of plant transformation.
The system reported for Agrobacterium-mediated transformation relies on sonication-induced tissue wounding to provide an entry point for the bacterium (Finer \& Trick, 1997). SAAT or sonication-assisted Agrobacterium-mediated transformation has been used for transforming various tissue types and plant species (Jiang et al., 2004; Zaragoza et al., 2004). Although stable transformants of Ohio buckeye and soybean have been produced (Trick \& Finer, 1997), fertile plants have not yet been recovered. For SAAT, plant tissue is sonicated in a bath sonicator in the presence of Agrobacterium for short periods of time. Ultrasound waves cause microwounds to form on the surface and deep within the plant tissue. Wounding due to sonication creates and entry point for the bacteria and may stimulate the production of signaling molecules (acetosyringone) involved in the T-DNA transfer process.

Bombardment of plant tissues with microprojectiles is an alternative effective method of wounding to promote Agrobacterium-mediated transformation. Particle bombardment methods using Agrobacterium were previously used to transform tobacco leaves and sunflower apical meristems (Bidney et al., 1992), banana meristems (May et al., 1995) and common and tepary bean meristems (Brasileiro et al., 1996) and soybean embryogenic tissue (Droste et al., 2000). This method is based on micro wounding of tissue by particle bombardment prior to inoculation with an Agrobacterium suspension and combines the advantages of the Agrobacterium with the ability of particle bombardment to generate microwounds, thus enhancing the attachment of bacteria and subsequent gene transfer (Droste et al., 2000). The results of these transformation protocols are difficult to compare due to differences in plant species, physiological status of the source tissue, type of explant and culture system. In spite of these differences, the microwounds caused by particle bombardment can enhance the Agrobacterium-mediated transformation frequency in different target tissues. Although the positive GUS assays only demonstrate transient expression of the introduced gene, the described method holds much promise to enhance Agrobacterium infection and to obtain stable transformation of soybean (Droste et al., 2000).

\section{TRACKING TRANSFORMATION}

Optimization and success of transformation can be facilitated and checked out by the use of selectable marker and reporter genes, which are excellent for tracking transformation events and are frequently used in transformation protocols. Using genetic engineering, these genes can be placed 
under regulatory control of specific promoters, making their expression associated to the transformation process.

\section{SELECTABLE MARKER GENES}

The expression of selectable marker genes allows proliferation of transformed cells on otherwise inhibitory levels of a compound, normally lethal to plant cells. Antibiotic resistance is the most common type of selectable marker. A gene for antibiotic resistance is usually fused with the reporter gene and gene of interest. Antibiotic resistance genes are typically chimeric bacterial genes that can be inserted into the T-DNA portion of the $\mathrm{Ti}$ plasmid of Agrobacterium (Fraley et al., 1983). The resistance gene usually codes for an enzyme that inactivates the antibiotic using phosphorylation (Gritz \& Davies, 1983). Two frequently used selective markers that employ antibiotics as the selective agent are neomycin phosphotransferase II (NPT II) and hygromycin phosphotransferase (HPT). When antibiotics such as kanamycin or hygromycin are present in the tissue culture media, transformed cells will continue to divide while untransformed cells will slowly die (Hames et al., 1993). The hpt gene is a good selectable marker to use in soybean transformation work while the use of $n p t$ II has not generated consistent results. The antibiotic hygromycin is very toxic to plant cells and expression of the $h p t$ gene effectively causes insensivity to hygromycin in transformed cells (Larkin, 2001).

Aragão et al. (2000) reported a system to select transgenic meristematic cells after the physical introduction of a mutant ahas gene by using a selection system based on the use of imazapyr, a herbicidal molecule of the imidazolinone class capable of systemically translocating and concentrating in the apical meristematic region of the plant. The mechanism of action of imazapyr is the inhibition of the enzymatic activity of acetohydroxyacid synthase [AHAS; acetolactate synthase, acetolactate pyruvate-lyase (carboxilating), EC 4.1.3.18], which catalyses the initial step in the biosynthesis of isoleucine, leucine and valine (Shaner et al. 1984). This selectable marker system, combined with an improved multiple-shooting induction protocol, resulted in a significant increase in the recovery of fertile, transgenic material compared with standard soybean transformation protocols (Aragão et al., 2000). Zhang et al. (1999) reported other herbicide resistance marker gene for soybean, gene bar encodes a phosphinothricin acetyl-transferase enzyme (PAT), which inactivates the herbicide phosphinothricin (PPT).

\section{REPORTER GENES}

Gene expression dynamics can often be monitored through the use of reporter genes. These genes are designed to visually reveal the expression of transgenes through destructive or non-destructive procedures. The Escherichia coli lacZ gene was one of the first to be used as a reporter. The lacZ gene encodes a $\beta$-galactosidase protein, which has been widely characterized genetically and biochemically (Lewin, 1997; 2000). This reporter gene was initially used to analyze gene expression in yeast (Larson et al., 1983) and later introduced into tobacco (Teeri et al., 1989). The main problem with this reporter gene is the background level of the $\beta$-galactosidase enzyme in plants. Another gene that was widely used for the analysis of transgene expression encodes the chloramphenicol acetyltransferase (CAT) protein (Shaw et al., 1980). The cat gene was successfully introduced into different eukaryotic organisms, such as yeast (Cohen et al., 1980), mammalian cells (Gorman et al., 1981), Drosophila (Di Nocera \& Dawid, 1983), tobacco (HerreraEstrella et al., 1984) and several Brassica species (Charest et al., 1989). The CAT reporter system was a suitable marker for some but not all plant species. Charest et al. (1989) found that some Brassica species had high levels of endogenous CAT activity and the response of unknown inhibitors, drastically reduced the levels of expression of the bacterial CAT in transgenic plants. These problems and the lack of a histochemical detection method limited the applications of cat as a reporter gene for plant transformation.

Some of the problems encountered with the cat and lacZ genes were solved by the reporter gene system GUS (Jefferson et al., 1986). The GUS reporter system (Jefferson, 1987; Jefferson et al., 1987) utilizes a bacterial gene from Escherichia coli (uidA) coding for a $\beta$-glucuronidase (GUS) and consists in placing this gene in the Ti-plasmid, which is transferred to plant cells following infection. When the plant tissue is assayed, transformation events are indicated by blue spots, which are a result of the enzymatic cleaving of an artificial substrate to give a blue product. The addition of a plant intron to the GUS gene directs expression only in plant cells (Ohta et al., 1990; Vancanneyt et al., 1990) with no problem of background expression in Agrobacterium. Although the GUS system is commonly used, the GUS histochemical assay utilizes cyanide, which kills the tissue, and requires overnight incubation for visualization. Due to the low content or absence of endogenous GUS activity in most plants, the uidA gene became one of the most widely-used reporter genes in eukaryotic systems. Unlike the lac $Z$ and cat reporter genes, the uidA gene expression could be quantified relatively easily 
using a fluorometric assay. This detection system is an inexpensive and sensitive method to assay gene expression; however, the detection assay is destructive, making it impossible to analyze the same piece of tissue over time.

For all these reasons the GUS reporter system was successfully used with different plant species (Jefferson et al., 1987; Kavanagh et al., 1988; Christou et al., 1989; Christou \& Swain, 1990; Huang \& Levings, 1995; Higuchi et al., 2001). Transformation experiments with soybean mostly use the GUS reporter system for determining gene expression and integration.

\section{GREEN FLUORESCENT PROTEIN ( $g f p$ ) RE- PORTER SYSTEM}

A better reporter system would not require killing the tissue and would permit rapid or immediate evaluation of gene expression directly in living tissues. So a new and simpler reporter system was developed which uses the green fluorescent protein (GFP) from jellyfish (Aquorea victoria). This reporter gene does not require a destructive staining procedure and allows direct viewing of gene expression in living plant tissue (Haseloff \& Amos, 1995). Similar to the GUS reporter system, $g f p$ can be introduced into plants using the Ti-plasmid. Following T-DNA transfer, GFP can be viewed directly in living tissues with blue light excitation. The GFP reporter system permits detection of labeled protein within cells and monitoring plant cells expressing $g f p$ directly within growing plant tissue (Haseloff \& Siemering, 1998).

Since the $g f p$ gene was first reported as a useful marker for gene expression in Escherichia coli and Caenorhabditis elegans by Chalfie et al. (1994), it has been modified by several laboratories to suit different purposes (Heim et al., 1994; Haseloff et al., 1997). Modification for plants include elimination of a cryptic intron, alteration in codon usage, changes in the chromophore leading to different excitation and emission spectra, targeting to the endoplasmic reticulum (ER) (Haseloff \& Siemering, 1998) and mitochondria (Benichou et al., 2003), and understanding the morphology and dynamics of the plant secretory pathway (Brandizzi et al., 2004).

GFP has been used as a reporter system for identifying transformation events in Arabidopsis thaliana (Haseloff et al., 1997; Ueda et al., 2003; Chang et al., 2005), apple (Maximova et al., 1998), rice (Vain et al., 1993), sugarcane, maize, lettuce, tobacco (Elliott et al., 1999), soybean (Ponappa et al., 1999), oat (Kaeppler et al., 2000), onion (Eady et al., 2000), wheat (Jordan, 2000), leek and garlic (Eady et al., 2005). The GFP reporter system has also been used for identifying successful plastid transformation events in potato (Sidorov et al., 1999). The $g f p$ gene has successfully been used as a scorable marker to evaluate plant transformation efficiency using Agrobacterium tumefaciens (Grebenok et al., 1997) and particle bombardment (Ponappa et al., 1999). The gene could be expressed as early as $1.5 \mathrm{~h}$ following introduction (Ponappa et al., 1999) and, since its detection is nondestructive, $g f p$ expression could be followed over extended periods of time. GFP has also been used as a reporter to analyze the compartmentalization and movement of proteins over time in living plant cells using confocal microscopy (Haseloff \& Siemering, 1998; Benichou et al., 2003).

As the original $g f p$ gene comes from the jellyfish, the coding region was modified to permit expression in plant cells. Codon usage of the gene was altered to stop splicing of a cryptic intron from the coding sequence (Haseloff et al., 1997). The unmodified $g f p$ contains an 84 nucleotide sequence that plants recognize as an intron and is efficiently spliced from the RNA transcript, resulting in little or no expression of $g f p$ (Haseloff et al., 1997). Using a modified $g f p$, $m g f p 4$, expression problems resulting from cryptic intron processing were eliminated for many plants. Although the $m g f p 4$ gene is clearly an effective reporter gene, brightly fluorescing transformants containing high levels of GFP were difficult to regenerate into fertile plants (Haseloff et al., 1997). GFP in plants accumulates in the cytoplasm and nucleoplasm, while in jellyfish, GFP is compartmentalized in cytoplasmic granules. GFP in plants may have a mildly toxic effect due to fluorescent properties of the protein and accumulation in the nucleoplasm. In order to overcome this problem $m g f p 5-E R$ was produced, which has targeting peptides fused to GFP to direct the protein to endoplasmic reticulum (ER). With this modification, fertile plants have been regenerated more consistently (Haseloff \& Siemering, 1998).

Unlike $m g f p 4, m g f p 5$-ER lacks temperature sensitivity found in the wild-type GFP. Wild-type GFP must undergo proper folding with specific temperature requirements to maintain its fluorescent properties (Haseloff \& Siemering, 1998). In addition to better protein folding, $m g f p 5$-ER has excitation peaks of 395 and $473 \mathrm{~nm}$. A broad excitation spectrum allows better GFP viewing with UV and blue light sources. The $m g f p 5-E R$ has shown to be an excellent reporter gene for lettuce and tobacco transformed by Agrobacterium (Elliott et al., 1999). Mgfp5-ER has also been used with success for transient expression in soybean embryogenic suspension cultures via particle bombardment (Ponappa et al., 1999).

The gene $g f p$ has been modified numerous times and there are several $g f p$ versions for plants. 
Modified versions, other than $m g f p 4$ and $m g f p 5-E R$, include: $S G F P-T Y G$ which produces a protein with a single excitation peak in blue light (Chiu et al., 1996), $s m g f p$ which is a soluble modified $m g f p 4$ (Davis \& Vierstra, 1998), $p g f p$ which is a modified wild type GFP (Pang et al., 1996), and $s G F P 65 T$ which is a modified $p g f p$ containing a Ser-to-Thr mutation at amino acid 65 (Pang et al., 1996). Different versions of $g f p$ have varying levels of fluorescence. These differences may be dependent upon the transformed species, promoter and termination sequences, or gene insertion sites (Wachter, 2005). In the future, selective markers may not be needed, but while the intricacies of GFP expression are not understood, selective markers are helpful in providing an advantage to identifying successful transformation events.

\section{OVERCOMING LIMITATIONS}

The success of Agrobacterium-mediated transformation may rely on specific plant-bacterium interactions. Soybean is a difficult crop to transform with Agrobacterium, and it is until now unclear why soybean transformation using this biological vector is inefficient. Plant-bacterium interactions may prohibit or negatively affect the transformation process in soybean embryogenic tissues.

To overcome the limitations of Agrobacteriummediated transformation of soybean, some procedures have been assayed. The SAAT technique described previously, which relies on sonication-induced tissue wounding to provide an entry point for the bacterium, is one of them. A variety of tissue types can be used for SAAT, including proliferative embryogenic tissue maintained on semi-solid media. This tissue type is called ' $\mathrm{D}-20$ tissue' because it is maintained on media containing $20 \mathrm{mg} \mathrm{L}^{-1}$ of 2, 4-D (Santarém \& Finer, 1999). D20 tissue subjected to SAAT was also monitored for transient transformation using the $m g f p 5-E R$ gene described previously. High levels of GFP transient expression are often seen in D20 tissues subjected to SAAT, but D20 tissues subjected to Agrobacterium alone often exhibit little or no GFP expression (Larkin, 2001). This can indicate the possible relationship between expression levels of plant defense genes and transient transformation of D20 tissues subjected to SAAT, as indicated by the GFP reporter system.

Another problem is tissue necrosis, simply defined as tissue browning, verified when the Agrobacterium-mediated system is used. Antioxidants are often used in co-culture media to reduce tissue necrosis caused by the interaction between plant cells and Agrobacterium. During the interactions between Agrobacterium and plant cells, elevated peroxidase activity and subsequent oxidation may cause tissue ne- crosis and cell death; symptoms which are characteristic of the hypersensitive response (HR) (Perl et al., 1996). Tissue necrosis as a result of Agrobacteriummediated transformation has been demonstrated with meristematic explants of sugarcane (Enríquez-Obregón et al., 1997) and embryogenic tissues of grape (Perl et al., 1996). Addition of antioxidants to co-culture or pretreatment media has been shown to improve Agrobacterium-mediated transformation for Craterostigma (Furini et al., 1994), grape (Perl et al., 1996; Mozsár et al., 1998), sugarcane (EnríquezObregón et al., 1997), and rice (Enríquez-Obregón et al., 1999). Use of media supplemented with antioxidants lessens tissue necrosis sometimes associated with plant-bacterium interactions.

The response of soybean tissue to wounding and to Agrobacterium infection may strongly influence transformation as well. Plant defense responses are an intricate part of plant tissue health and productivity. Plants produce signal molecules that induce resistance responses due to wounding or pathogen attack. Induced defense responses include reinforcement of cell walls, synthesis of antioxidants, followed by programmed cell death of cells located at the site of pathogen invasion (Lamb et al., 1989; Zhu et al., 1999). A large set of plant defense genes is involved in plant defense response and studies on the expression levels of these plant defense genes can be used to better understand the relationship between stress responses and plant tissue health. Monitoring the accumulation of defense response gene transcripts over time may provide insights into the intricate relationship between pathogen invasion and plant response. A variety of genes involved in plant defense responses have already been identified in soybean (Larkin, 2001).

Perhaps the best characterized plant defense genes are members of the chalcone synthase (CHS) family. Chalcone synthase is an enzyme in the phenylpropanoid pathway that is responsible for flavonoid/isoflavonoid production. Flavonols are plant defense compounds involved in protection from wounding, pathogen attack, and UV light. Pathogen invasion or wounding, results in enhanced CHS expression and subsequent flavonoid production. Soybean contains at least seven complete copies of the chs gene (Akada \& Dube, 1995) and some of these genes are tightly clustered within a $10 \mathrm{~Kb}$ region of the soybean genome (Matsumura et al., 2005). The members of this multigene family are differentially regulated, which provides some insight into the complexity of gene regulation. For instance, expression of the various family members is differentially induced by the symbiotic relationship with Rhyzobium and the pathogenic relationship with Agrobacterium (Wingender et al., 1989). 
Elicitors, wounding, or infection induces plant defense responses. These stresses stimulate transcriptional activators, which promote the expression of plant defense genes such as chs. Induction of chs has been shown to occur in as little as two to three minutes following elicitor treatment of cultured bean cells (Lamb et al., 1989). Also, chs transcript levels have been shown to increase in soybean cell cultures infected with Agrobacterium, and peak accumulation of chs transcripts occurring between four and eight hours after treating seedlings with Agrobacterium has been reported (Wingender et al., 1989). The multiple genes encoding CHS may be differentially regulated in soybean tissue, but some members of the family are quickly stimulated in response to Agrobacterium invasion or tissue wounding.

Because various plant stresses induce chs expression, relative levels of CHS were quantified from D20 tissue exposed to SAAT, sonication, Agrobacterium, and non-treated control tissue (Larkin, 2001). Visual inspection of the data at the two minute time point indicated that CHS levels increased in tissues subjected to Agrobacterium alone. Tissues sonicated alone or treated with SAAT had reduced CHS levels, similar to the basal levels of untreated tissues. The reduction in CHS expression seen in sonicated tissues indicates that sonication may prevent or decrease CHS expression. By studying the relative expression levels of chs, it may be possible to use CHS as a marker to study plant tissue health during transformation (Larkin, 2001).

\section{FINAL REMARKS}

Routine transformation protocols are limited in most grain legumes. The low success has been attributed to poor regeneration ability (especially via callus) and lack of compatible gene delivery methods, although some success has been achieved in soybean. One of the limitations for efficient plant transformation is the lack of understanding of gene expression during the selection and regeneration processes. Therefore, optimization of the transformation efficiency and reproducibility in different laboratories still represents a major goal of investigators. Although transgenic soybeans containing the target gene were produced, only a few viable transgenic lines could be generated. We believe this is because transformation methods have not yet been properly quantified and established. To improve the efficiency of transformation, more appropriate and precise methods need to be developed. For monitoring the efficiency of each step, the jellyfish green fluorescent protein (GFP) perfectly qualifies, because frequent evaluation of transgene expression could provide detailed information about regulation of gene expression in vitro. Nowadays, GFP is a useful reporter gene in soybean transformation and is also used as a tool to study gene expression dynamics in stably transformed clones. GFP can play an important role in the evaluation of transformation systems and in the avoidance of gene silencing. Recent progress in soybean transformation suggests that some systems will achieve the transformation efficiency required for functional genomics applications in the near future.

\section{ACKNOWLEDGEMENTS}

To Dr. John Finer and Dr. Robert Bouchard of The Ohio State University for their valuable advice as a research team and helpful contribution to the contents of this review.

\section{REFERENCES}

AKADA, S.; DUBE, S.K. Organization of soybean chalcone synthase gene clusters and characterization of a new member of the family. Plant Molecular Biology, v.29, p.189-199, 1995.

ALTPETER, F.; BAISAKH, N.; BEACHY, R.; BOCK, R.; CAPELL, T.; CHRISTOU, P.; DANIELL, H.; DATTA, K.; DATTA, S.; DIX, P.J.; FAUQUET, C.; HUANG, N.; KOHLI, A.; MOOIBROEK, H.; NICHOLSON, L.; NGUYEN, T.T.; NUGENT, G.; RAEMAKERS, K.; ROMANO, A.; SOMERS, D.A.; STOGER, E.; TAYLOR, N.; VISSER, R. Particle bombardment and the genetic enhancement of crops: myths and realities. Molecular Breeding, v.15, p.305-327, 2005.

ARAGÃO, F.J.L.; SAROKIN, L.; VIANNA, G.R.; RECH, E.L. Selection of transgenic meristematic cells utilizing a herbicidal molecule results in the recovery of fertile transgenic soybean [Glycine $\max (\mathrm{L}$.$) Merrill] plants at a high frequency.$ Theoretical and Applied Genetics, v.101, p.1-6, 2000.

BAILEY, M.A.; BOERMA, H.R.; PARROTT, W.A. Genotype effects on proliferative embryogenesis and plant regeneration of soybean. In Vitro Cellular and Developmental BiologyPlant, v.29, p.102--108, 1993.

BENICHOU, M.; LI, Z.; TOURNIER, B.; CHAVES, A.L.S.; ZEGZOUTI, H.; JAUNEAU, A.; DELALANDE, C.; LATCHÉ, A.; BOUZAYEN, M.; SPREMULLI, L.L.; PECH, J.-C. Tomato EF-Ts (mt), a functional translation elongation factor from higher plants. Plant Molecular Biology, v.53, p.411-422, 2003.

BIDNEY, D.; SCELONGE, C.; MARTICH, J.; BURRUS, M.; SIMS, L.; HUFFMAN, G. Microprojectile bombardment of plant tissues increases transformation frequency by Agrobacterium tumefaciens. Plant Molecular Biology, v.18, p.301-313, 1992.

BRANDIZZI, F.; IRONS, S.L.; JOHANSEN, J.; KOTZER, A.; NEUMANN, U. GFP is the way to glow: bioimaging of the plant endomembrane system. Journal of Microscopy, v.4, p.138158, 2004.

BRASILEIRO, A.C.M.; LIMA-ARAGÃO, F.J.; ROSSI, S.; DUSI, D.M.A.; GOMES-BARROS, L.M.; RECH, E.L. Susceptibility of common and tepary beans to Agrobacterium spp. strains and improvement of Agrobacterium-mediated transformation using microprojectile bombardment. Journal of the American Society for Horticultural Science, v.121, p.810-815, 1996.

CHALFIE, M.; TU, Y.; EUSKIRCHEN, G.; WARD, W.W.; PRASHER, D.C. Green fluorescent protein as a marker for gene expression. Science, v.263, p.802-805, 1994. 
CHANG, F.R.; HAYASHI, K.; CHUA, N.H.; KAMIO, S.; HUANG, Z.Y.; NOZAKI, H.; WU, Y.C. The transgenic Arabidopsis plant system, pER8-GFP, as a powerful tool in searching for natural product estrogen-agonists/antagonists. Journal of Natural Products, v.7, p.971-973, 2005.

CHAREST, P.J.; IYER, V.N.; MIKI, B.L. Factors affecting the use of chloramphenicol acetyltransferase as a marker for Brassica genetic transformation. Plant Cell Reports, v.7, p.628-631, 1989.

CHEE, P.P.; FOBER, K.A.; SLIGHTOM, J.L. Transformation of soybean (Glycine max) by infecting germinating seeds with Agrobacterium tumefaciens. Plant Physiology, v.91, p.1212$-1218,1989$.

CHIU, W.L.; NIWA, Y.; ZENG, W.; HIRANO, T.; KOBAYASHI, H.; SHEEN, J. Engineered GFP as a vital reporter in plants. Current Biology, v.6, p.325-330, 1996.

CHRISTIANSON, M.L.; WARNICK, D.A.; CARLSON, D.S. A morphogenetically competent soybean suspension culture. Science, v.67, p.632-634, 1983.

CHRISTOU, P.; SWAIN, W.F. Cotransformation frequencies of foreign genes in soybean cell cultures. Theoretical and Applied Genetics, v.79, p.337-341, 1990.

CHRISTOU, P.; SWAIN, W.F.; YANG, N.S.; McCABE, D.E. Inheritance expression of foreign genes in transgenic soybean plants. Proceedings of the National Academy of Sciences of the USA, v.86, p.7500-7504, 1989.

CHRISTOU, P.; FORD, T.L.; KOFRON, M. Rice genetic engineering: a review. Trends in Biotechnology, v.10, p.239246, 1992.

CLEMENTE, T.E.; LAVALlEE, B.J.; HOWE, A.R.; CONNERWARD, D.; ROZMAN, R.J.; HUNTER, P.E.; BROYLES, D.L.; KASTEN, D.S.; HINCHEE, M.A. Progeny analysis of glyphosate selected transgenic soybeans derived from Agrobacteriummediated transformation. Crop Science, v.40, p.797-803, 2000 .

COHEN, L.D.; ECCLESHALL, T.R.; NEEDLEMAN, R.B.; FEDEROFF, H.; BUCFERER, B.A.; MARMUR, L. Functional expression in yeast of the Escherichia-coli plasmid gene coding for chloramphenicol acetyl transferase. Proceedings of the National Academy of Sciences of the USA, v.77, p.1078$1082,1980$.

CORRE, F.; HENRY, Y.; RODE, A.; HARTMANN, C. Em gene expression during somatic embryogenesis in the monocot Triticum aestivum L. Plant Science, v.117, p.139-149, 1996. CROSSWAY, A.; OAKES, J.V.; IRVINE, J.M.; WARD, B.; KNAUF, V.C.; SHEWMAKER, C.K. Integration of foreign DNA following microinjection of tobacco mesophyll protoplasts. Molecular \& General Genetics, v.202, p.179-185, 1986

DAI, S.; ZHENG, P.; MARMEY, P.; ZHANG, S.; TIAN, W.; CHEN, S.; BEACHY, R.N.; FAUQUET, C. Comparative analysis of transgenic rice plants obtained by Agrobacterium-mediated transformation and particle bombardment. Molecular Breeding, v.7, p.25-33, 2001.

DANIELL, H.; KUMAR, S.; DUFOURMANTEL, N. Breakthrough in chloroplast genetic engineering of agronomically important crops. Trends in Biotechnology, v.5, p.238-245, 2005.

DATTA, S.K.; PETERHANS, A.; DATTA, K.; POTRYKUS, I. Genetically engineered fertile Indica-rice plants recovered from protoplasts. Bio/Technology, v.8, p.736-740, 1990.

DAVIS, S.J.; VIESTRA, R.D. Soluble, highly fluorescent variants of green fluorescent protein (GFP) for use in higher plants. Plant Molecular Biology, v.36, p.521-528, 1998.

DELZER, B.W.; SOMERS, D.A.; ORF, J.H. Agrobacterium tumefaciens susceptibility and plant regeneration of 10 soybean genotypes in maturity groups 00 to II. Crop Science, v.30, p.320-322, 1990 .

DI NOCERA, P.P.; DAWID, L.B. Transient expression of genes introduced into cultured cells of Drosophila. Proceedings of the National Academy of Sciences, v.80, p.7095-7098, 1983 .
DROSTE, A.; PASQUALI, G.; BODANESE-ZANETTINI, M.H.. Integrated bombardment and Agrobacterium transformation system: an alternative method for soybean transformation. Plant Molecular Biology Reporter, v.18, p.51-59, 2000.

EADY, C.; WELD, R.; LISTER, C. Agrobacterium tumefaciensmediated transformation and regeneration of onion (Allium cepa L.). Plant Cell Reports, v.19, p.376-381, 2000.

EADY, C.; DAVIS, S.; CATANACH, A.; KENEL, F.; HUNGER, S. Agrobacterium tumefaciens-mediated transformation of leek (Allium porrum) and garlic (Allium sativum). Plant Cell Reports, v.4, p.209-215, 2005.

ELLIOTT, A.R.; CAMPBELL, J.A.; DUGDALE, B.; BRETTELL, R.I.S.; GROF, C.P.L. Green-fluorescent protein facilitates rapid in vivo detection of genetically transformed plant cells. Plant Cell Reports, v.18, p.707-714, 1999.

ENRÍQUEZ-OBREGON，G.A.; VAZQUEZ-PADRON，R.I.; PRIETO-SAMSONOV, D.L.; PEREZ, M.; SELMAN-HOUSEIN, G. Genetic transformation of sugarcane by Agrobacterium tumefaciens using antioxidant compounds. Biotecnologia Aplicada, v.14, p.169-174, 1997.

ENRÍQUEZ-OBREGON, G.A.; PRIETO-SAMSONOV, D.L.; DE LA RIVA, G.A.; PEREZ, M.; SELMAN-HOUSEIN, G.; VAZQUEZPADRON, R.I. Agrobacterium-mediated Japonica rice transformation: a procedure assisted by an antinecrotic treatment. Plant Cell Tissue and Organ Culture, v.59, p.159-168, 1999.

FINER, J.J. Apical proliferation of embryogenic tissue of soybean [Glycine $\max ($ L.) Merrill]. Plant Cell Reports, v.7, p.238$241,1988$.

FINER, J.J.; NAGASAWA, A. Development of an embryogenic suspension culture of soybean (Glycine max Merrill.). Plant Cell, Tissue and Organ Culture, v.15, p.125--136, 1988.

FINER, J.J.; McMULLEN, M.D. Transformation of soybean via particle bombardment of embryogenic suspension culture tissue. In Vitro Cellular and Developmental Biology-Plant, v.27, p.115-182, 1991.

FINER, J.J.; FINER, K.R.; SANTAREM, E.R. Plant cell transformation, physical methods for. In: MYERS, R.A. Encyclopedia of molecular biology and molecular medicine. Weinheim: VCH, 1996a. p.458-465.

FINER, J.J.; CHENG, T.S.; VERMA, D.P.S. Soybean Transformation: Technologies and Progress. In: VERMA, D.P.S.; SHOEMAKER, R.C. (Ed.) Soybean biotechnology. Arlington: CABI, 1996b. p.249-263. (Biotechnology in Agriculture, 14).

FINER, J.J.; TRICK, H.N. Method for transforming plant tissue by sonication. 1997. US Patent 5/693/512.

FOWKE, L.; ATTREE, S. Conifer somatic embryogenesis: studies of embryo development and the cell biology of conifer cells and protoplasts. Plant Tissue Culture and Biotechnology, v.2, p.124-130, 1996.

FRALEY, R.T.; ROGERS, S.G.; HORSCH, R.B.; SANDERS, P.R.; FLICK, J.S.; ADAMS, S.P.; BITTNER, M.L.; BRAND, L.A.; FINK, C.L.; FRY, J.S.; GALLUPPI, G.R.; GOLDBERG, S.B.; HOFFMANN, N.L.; WOO, S.G. Expression of bacterial genes in plant cells. Proceedings of the National Academy of Sciences of the USA, v.80, p.4803-4807, 1983.

FRAME, B.R.; DRAYTON, P.R.; BAGNALL, S.V.; LEWNAU, C.J.; BULLOCK, W.P.; WILSON, H.M.; DUNWELL, J.M.; THOMPSON, J.A.; WANG, K. Production of fertile transgenic maize plants by silicon-carbide whisker-mediated transformation. Plant Journal, v.6, p.941-948, 1994

FROMM, M.E.; TAYLOR, L.P.; WALBOT, V. Stable transformation of maize after gene-transfer by electroporation. Nature, v.319, p.791-793, 1986.

FURINI, A.; KONCZ, C.; SALAMINI, F.; BARTELS, D. Agrobacterium-mediated transformation of the desiccationtolerant plant Craterostigma plantagineum. Plant Cell Reports, v.14, p.102-106, 1994.

GELVIN, S.B. Agrobacterium-mediated plant transformation: the biology behind the "gene-jockeying" tool. Microbiology and Molecular Biology Reviews, v.1, p.16-37, 2003. 
GODWIN, I.; TODD, G.; FORD-LOYD, B.; NEWBURY, H.I. The effects of acetosyringone and $\mathrm{pH}$ on Agrobacterium-mediated transformation vary according to plant species. Plant Cell Reports, v.9, p.671-675, 1991.

GORMAN, C.M.; MOFFAT, L.F.; HOWARD, B.H. Chloramphenicol acetyl transferase expression in eukaryotic cells. Journal of Cell Biology, v.91, p.363A, 1981.

GREBENOK, R.J.; LAMBERT, G.M.; GALBRAITH, D.W. Characterization of the targeted nuclear accumulation of GFP within the cells of transgenic plants. The Plant Journal, v.12, p.685-696, 1997.

GRITZ, L.; DAVIES, J. Plasmid-encoded hygromycin B resistance: the sequence of hygromycin B phosphotransferase gene and its expression in Escherichia coli and Saccharomyces cerevisiae. Gene, v.25, p.179-188, 1983.

HADI, M.Z.; McMULLEN, M.D.; FINER, J.J. Transformation of 12 different plasmids into soybean via particle bombardment. Plant Cell Reports, v.15, p.500-505, 1996.

HAMES, B; RICKWOOD, D.; CROY, R. Plant molecular biology LabFax. New York: Academic Press, 1993. 382p.

HANSEN, G.; DAS, A.; CHILTON, M.D. Constitutive expression of the virulence genes improves the efficiency of plant transformation by Agrobacterium. Proceedings of the National Academy of Sciences of the USA, v.91, p.76037607, 1994.

HANSEN, G.; WRIGHT, M. Recent advances in the transformation of plants. Trends in Plant Science, v.4, p.226-231, 1999.

HASELOFF, J.; AMOS, B. GFP in plants. Trends in Genetics, v. 8, p. 328-329, 1995.

HASELOFF, J.; SIEMERING, K.R. The uses of green fluorescent protein in plants. In: CHALTIE, M.; KAIN, S. Green fluorescent protein: properties, applications and protocols. New York: Wiley-Liss Press, 1998. p.191-219.

HASELOFF, J.; SIEMERING, K.R.; PRASHER, D.C.; HODGE, S. Removal of a cryptic intron and sub cellular localization of green fluorescent protein are required to mark transgenic Arabidopsis plants brightly. Proceedings of the National Academy of Sciences of the USA, v.94, p.2122-2127, 1997.

HAZEL, C.B.; KLEIN, T.M.; ANIS, M.; WILDE, L.I.D.; PARROTT, W.A. Growth characteristics and transformability of soybean embryogenic cultures. Plant Cell Reports, v.17, p.765-772, 1998

HEIM, R.; PRASHER, D.C.; TSIEN, R.Y. Wavelength mutations and posttranslational autoxidation of green fluorescent protein. Proceedings of the National Academy of Sciences of the USA, v.91, p.12501-12504, 1994.

HERRERA-ESTRELLA, L.; BROECK, G. van den; MAENHAUT, R.; MONTAGU, M. van; SCHELL, J.; TIMKO, M.; CASHMORE, A. Light inducible and chloroplast associated expression of a chimeric gene introduced into Nicotiana tabacum using a Ti plasmid vector. Nature, v.310, p.115-120, 1984.

HIGUCHI, K.; TANI, M.; NAKANISHI, H.; YOSHIWARA, T.; GOTO, F.; NISHIZAWA, N.K.; MORI, S. The expression of a barley HvNAS1 nicotianamine synthase gene promoter-gus fusion gene in transgenic tobacco is induced by Fe-deficiency in roots. Bioscience, Biotechnology and Biochemistry, v.7, p.1692-1696, 2001

HINCHEE, M.A.W.; CONNOR-WARD, D.V.; NEWELL, C.A.; McDONNELL, R.E.; SATO, S.J.; GASSER, C.S.; FISCHHOFF, D.A.; RE D.B.; FRALEY, R.T.; HORSCH, R.B. Production of transgenic soybean plants using Agrobacterium-mediated DNA transfer. Bio/Technology, v.6, p.915-922, 1988.

HORSCH, R.B.; FRY, J.E.; HOFFMANN, N.L.; EICHHOLTZ, D.; ROGERS, S.G.; FRALEY, R.T. A simple and general method for transferring genes into plants. Science, v.227, p.1229-1231, 1985.

HUANG, J.; LEVINGS 3rd, C.S. Functional analysis of a recently originating, atypical presequence: mitochondrial import and processing of GUS fusion proteins in transgenic tobacco and yeast. Plant Molecular Biology, v.3, p.519-533, 1995.
JAMES, C. Global status of commercialized Biotech/GM Crops: 2005. Ithaca: ISAAA, 2005. (Briefs, 34).

JASIK, J.; SALAJOVA, T.; SALAJ, J. Developmental anatomy and ultra structure of early somatic embryos in European black pine (Pinus nigra Arn.). Protoplasma, v.11, p.205-211, 1995.

JEFFERSON, R.A. Assaying chimeric genes in plants: the GUS gene fusion system. Plant Molecular Biology Report, v.5, p.387-405, 1987.

JEFFERSON, R.A.; BURGESS, S.M.; HIRSH, D. $\beta$-glucuronidase from Escherichia coli as a gene-fusion marker. Proceedings of the National Academy of Sciences of the USA, v.83, p. 8447-8451, 1986.

JEFFERSON, R.A.; KAVANAGH, T.A.; BEVAN, M. GUS fusions: $\beta$-glucuronidase as a sensitive and versatile gene fusion marker in higher plants. EMBO Journal, v.6, p.3901-3907, 1987.

JIANG, L.; MAOKA, T.; KOMORI, S.; FUKAMACHI, H.; KATO, H.; OGAWA, K. An efficient method for sonication assisted Agrobacterium-mediated transformation of coat protein (CP) coding genes into papaya (Carica papaya L.). Journal of Experimental Biology, v.3, p.189-198, 2004.

JORDAN, M.C. Green fluorescent protein as a visual marker for wheat transformation. Plant Cell Reports, v.19, p.1069-1075, 2000.

KAEPPLER, H.F.; MENON, G.K.; SKADSEN, R.W.; NUUTILA, A.M.; CARLSON, A.R. Transgenic oat plants via visual selection of cells expressing green fluorescent protein. Plant Cell Reports, v.19, p.661-666, 2000.

KAVANAGH, T.A.; JEFFERSON, R.A.; BEVAN, M.W. Targeting a foreign protein to chloroplasts using fusions to the transit peptide of a chlorophyll A-B protein. Molecular \& General Genetics, v.215, p.38-45, 1988.

KLEIN, T.M.; WOLF, E.D.; SANFORD, J.C. High-velocity microprojectiles for delivering nucleic acids into living cells. Nature, v.327, p.70-73, 1987

LAMB, C.J.; LAWTON, M.D.; DRON, M.; DIXON, R.A. Signals and Transduction Mechanisms for activation of plant defenses against microbial attack. Cell, v.56, p.215-224, 1989.

LARKIN, K.M. Optimization of soybean transformation using SAAT and GFP. Wooster: OARDC/OSU, 2001. 126p. (Thesis Master).

LARSON, G.P.; ITAKURA, K.; ITO, H.; ROSSI, J.J. Saccharomyces cerevisiae actin--Escherichia coli lacZ gene fusions: syntheticoligonucleotide-mediated deletion of the 309 base pair intervening sequence in the actin gene. Gene, v.22, p.31-39, 1983.

LEWIN, B. Genes VI. New York: Oxford University Press, 1997. $1260 \mathrm{p}$.

LEWIN, B. Genes VII. New York: Oxford University Press, 2000. $990 \mathrm{p}$.

MATSUMURA, H.; WATANABE, S.; HARADA, K.; SENDA, M.; AKADA, S.; KAWASAKI, S.; DUBOUZET, E.G.; MINAKA, N.; TAKAHASHI, R. Molecular linkage mapping and phylogeny of the chalcone synthase multigene family in soybean. Theoretical and Applied Genetics, v.7, p.1203-1209, 2005.

MAXIMOVA, S.N.; DANDEKAR, A.M.; GUILTINAN, M.J. Investigation of Agrobacterium-mediated transformation of apple using green fluorescent protein: high transient expression and low stable transformation suggest that factors other than T-DNA transfer are rate-limiting. Plant Molecular Biology, v.37, p.549-559, 1998.

MAY, G.D.; AFZA, R.; MASON, H.S.; WIECKO, A.; NOVAK, F.J.; ARNTZEN, C.J. Generation of transgenic banana (Musa acuminata) plants via Agrobacterium-mediated transformation. Bio/Technology, v.13, p.486-492, 1995.

McCABE, D.; SWAIN, W.F.; MARTINELL, B.J.; CHRISTOU, P. Stable transformation of soybean (Glycine max) by particle acceleration. Bio/Technology, v.6, p.923-926, 1988.

MEURER, C.A.; DINKINS, R.D.; COLLINS, G.B. Factors affecting soybean cotyledonary node transformation. Plant Cell Reports, v.18, p.180-186, 1998. 
MISRA, S. Conifer zygotic embryogenesis, somatic embryogenesis, and seed germination: Biochemical and molecular advances. Seed Scientific Research, v.4, p.357-384, 1994.

MOZSÁR, J.; VICZIÁN, O.; SÜLE, S. Agrobacterium-mediated genetic transformation of an interspecific grapevine. Vitis, v.37, p.127-130, 1998.

NANDADEVA, Y.L.; LUPI, C.G.; MEYER, C.S.; DEVI, P.S.; POTRYKUS, I.; BILANG, R. Microprojectile-mediated transient and integrative transformation of rice embryogenic suspension cells: effects of osmotic cell conditioning and of the physical configuration of plasmid DNA. Plant Cell Reports, v.18, p.500-504, 1999.

NEGRUTIU, I.; SHILLITO, R.D.; POTRYKUS, I.; BIASINI, G.; SALA, F. Hybrid genes in the analysis of transformation conditions. I. Setting up a simple method for direct gene transfer in plant protoplasts. Plant Molecular Biology, v.8, p.363373, 1987.

OHTA, S.; MITA, S.; HATTORI, T.; NAKAMURA, K. Construction and expression in tobacco of a $\beta$-glucuronidase (GUS) reporter gene containing an intron within the coding sequence. Plant Cell Physiology, v.31, p.805-813, 1990.

OLHOFT, P.M.; FLAGEL, L.E.; DONOVAN, C.M.; SOMERS, D.A. Efficient soybean transformation using hygromycin B selection in the cotyledonary-node method. Planta, v.216, p.723-735, 2003.

OWENS, L.D.; CRESS, D.E. Genotypic variability of soybean response to Agrobacterium strains harboring the $\mathrm{Ti}$ or $\mathrm{Ri}$ plasmids. Plant Physiology, v.77, p.87-94, 1985.

PANG, S.Z.; DEBOER, D.L.; WAN, Y.; YE, G.; LAYTON, J.G.; NEHER, M.K.; ARMSTRONG, C.L.; FRY, J.E.; HINSHEE, M.A.; FROMM, M.E. An improved green fluorescent protein gene as a vital marker in plants. Plant Physiology, v.112, p.893-900, 1996.

PARROTT, W.A.; HOFFMAN, L.M.; HILDEBRAND, D.F.; WILLIAMS, E.G.; COLLINS G.B. Recovery of primary transformants of soybean. Plant Cell Reports, v.7, p.615$617,1989$.

PARROTT, W.A.; ALL, J.N.; ADANG, M.J.; BAILEY, M.A.; BOERMA, H.R.; STEWART, C.N.J. Recovery and evaluation of soybean plants transgenic for a Bacillus thuringiensis var. Kurstaki insecticidal gene. In Vitro Cellular and Developmental Biology-Plant, v.30, p.144-149, 1994.

PATNAIK, D.; KHURANA, P. Germins and germin like proteins: an overview. Indian Journal of Experimental Biology, v.3, p.191-200, 2001.

PAZ, M.M.; MARTINEZ, J.C.; KALVIG, A.B.; FONGER, T.M.; WANG, K. Improved cotyledonary node method using an alternative explant derived from mature seed for efficient Agrobacterium-mediated soybean transformation. Plant Cell Reports, v.25, p.206-213, 2005.

PERL, A.; LOTAN, O.; ABU-ABIED, M.; HOLLAND, D. Establishment of an Agrobacterium-mediated transformation system for grape (Vitis vinifera L.): The role of antioxidants during grape-Agrobacterium interactions. Nature Biotechnology, v.14, p.624-628, 1996.

PONAPPA, T.; BRZOZOWSKI, A.E.; FINER, J.J. Transient expression and stable transformation of soybean using the jellyfish green fluorescent protein. Plant Cell Reports, v.19, p.6-12, 1999.

RAKOCZY-TROJANOWSKA, M. Alternative methods of plant transformation-a short review. Cellular \& Molecular Biology Letters, v.7, p.849-858, 2002.

RIVA, G.A.; GONZÁLEZ-CABRERA, J.; VÁZQUEZ-PADRON, R.; AYRA-PARDO, C. Agrobacterium tumefaciens: a natural tool for plant transformation. Nature Biotechnology, v.1, p.77-83, 1998

SANTARÉM, E.R.; FINER, J.J. Transformation of soybean [Glycine Max (L.) Merrill] using proliferative embryogenic tissue maintained on semi-solid medium. In Vitro Cellular and Developmental Biology-Plant, v.35, p.451-455, 1999.
SANTARÉM, E.R.; PELISSIER, B.; FINER, J.J. Effect of explant orientation, $\mathrm{pH}$, solidifying agent and wounding on initiation of soybean somatic embryos. In Vitro Cellular and Developmental Biology-Plant, v.33, p.13-19, 1997.

SANTOS, C.G.B.; MUNDSTOCK, E.; BODANESE-ZANETTINI, M.H. Genotype-specific normalization of soybean somatic embryogenesis through the use of an ethylene inhibitor. Plant Cell Reports, v.16, p.859-864, 1997.

SATO, S.; NEWELL, C.; KOLACZ, K.; TREDO, L.; FINER, J.J.; HINCHEE, M. Stable transformation via particle bombardment in two different soybean regeneration systems. Plant Cell Reports, v.12, p.408-413, 1993.

SCHMIDT, M.A.; TUCKER, D.M.; CAHOON, E.B.; PARROTT, W.A. Towards normalization of soybean somatic embryo maturation. Plant Cell Reports, v.24, p.383-391, 2005.

SHANER, D.L.; ANDERSON, P.C.; STIDHAM, M.A. Imidazolinones: potent inhibitors of acetohydryacid snythase. Plant Physiology, v.76, p.534-546, 1984.

SHAW, W.V.; PACKMAN, L.C.; BURLEIGH, B.D.; DELL, A.; MORRIS, H.R.; HARTSLEY, B.S. Primary structure of a chloramphenicol acetyl transferase EC-2.3.1.28 specified by R plasmids. Nature, v.282, p.870-872, 1980.

SHENG, J.; CITOVSKY, V. Agrobacterium-Plant cell DNA transport: have virulence proteins, will travel. The Plant Cell, v.8, p.1699-1710, 1996

SHILLITO, R.D.; SAUL, M.W.; PASZKOWSKI, J.; MULLER, M.; POTRYKUS I. High efficiency direct gene transfer to plants. Bio/Technology, v.3, p.1099-1103, 1985.

SIDOROV, V.A.; KASTEN, D.; PANG, S.; HAJDUKIEWICZ, P; STAUB, J.; NEHRA, N. Stable chloroplast transformation in potato: use of green fluorescent protein as a plastid marker. The Plant Journal, v.19, p.209-216, 1999.

STATCHEL, S.E.; MESSENS, E.; MONTAGU, M. van; ZAMBRYSKI, P. Identification of the signal molecules produced by wounded plant cells that activate T-DNA transfer in Agrobacterium tumefaciens. Nature, v.318, p.624-629, 1985.

STEWARD, F.C.; MAPES, M.O.; SMITH, J. Growth and organized development of cultured cells. 1. Growth and division of freely suspended cells. American Journal of Botany, v.45, p.693703, 1958.

TEERI, T.; LEHVASLAIHO, H.; FRANCK, M.; UOTILA, J.; HEINO, P.; PALVA, E.T.; VON MONTAGU, M.; HERRERAESTRELLA, L. Regulated expression of lac $Z$ gene fusions in tobacco. In: KURZ, W.G.W. (Ed.) Primary and secondary metabolism of plant cell cultures II. New York: Springer, 1989, p.274-280.

TINLAND, B. The integration of T-DNA into plant genomes. Trends in Plant Science, v.1, p.178-184, 1996.

TOWNSEND, J.A.; THOMAS, B.F. An improved method of Agrobacterium-mediated transformation of cultured soybean cells. 1993. US Patent WO 94/02620.

TRICK, H.N.; FINER, J.J. SAAT: sonication-assisted Agrobacteriummediated transformation. Transgenic Research, v.6, p.329336, 1997.

TRICK, H.N.; FINER, J.J. Sonication-assisted Agrobacteriummediated transformation of soybean [Glycine $\max (\mathrm{L}$.$) Merrill]$ embryogenic suspension culture tissue. Plant Cell Reports, v.17, p.482-488, 1998.

TRICK, H.N.; FINER, J.J. Induction of somatic embryogenesis and genetic transformation of Ohio buckeye (Aesculus glabra Willd.). In Vitro Cellular and Developmental BiologyPlant, v.35, p.57-60, 1999.

UEDA, K.; SAKAGUCHI, S.; KUMAGAI, F.; HASEZAWA, S.; QUADER, H.; KRISTEN, U. Development and disintegration of phragmoplasts in living cultured cells of a GFP: TUA6 transgenic Arabidopsis thaliana plant. Protoplasma, v.3-4, p.111-118, 2003.

VAIN, P.; KEEN, N.; MURILLO, J.; RATHUS, C.; NEMES, C.; FINER, J.J. Development of the particle inflow gun. Plant Cell Tissue and Organ Culture, v.33, p.237-246, 1993. 
VANCANNEYT, G.; SCHMIDT, R.; O'CONNOR-SANCHEZ, A.; WILLMITZER, L.; ROCHA-SOSA, M. Construction of an intron-containing marker gene: Splicing of the intron in transgenic plants and its use in monitoring early events in Agrobacterium-mediated plant transformation. Molecular and General Genetics, v.220, p.245-250, 1990.

VAUCHERET, H.; BECLIN, C.; ELMAYAN, T.; FEUERBACH, F.; GODON, C.; MOREL, J.B.; MOURRAIN, P.; PALAUQUI, J.C.; VERNHETTES, S. Transgene-induced gene silencing in plants. Plant Journal, v.16, p.651-659, 1998.

WACHTER, R. The Family of GFP-Like Proteins: Structure, Function, Photophysics and Biosensor Applications. Photochemistry and Photobiology, v.82, p.339-344, 2005.

WINGENDER, R.; ROHRIG, H.; HORICKE, C.; WING, D.; SCHELL, J. Differential regulation of soybean chalcone synthase genes in plant defense, symbiosis, and upon environmental stimuli. Molecular and General Genetics, v.218, p.315322,1989

YAN, B.; SRINIVAS REDDY, M.S.; COLLINS, G.B.; DINKINS, R.B. Agrobacterium tumefaciens -mediated transformation of soybean [Glycine $\max (\mathrm{L}$.$) Merrill] using immature zygotic$ cotyledon explants. Plant Cell Reports, v.19, p.1090-1097, 2000 .
ZAMBRYSKI, P. Basic processes underlying Agrobacteriummediated DNA transfer to plant cells. Annual Review in Genetics, v.22, p.1-30, 1988 .

ZARAGOZA, C.; MUNOZ-BERTOMEU, J.; ARRILlAGA, I. Regeneration of herbicide-tolerant black locust transgenic plants by SAAT. Plant Cell Reports, v.11, p.832-838, 2004.

ZHANG, Z.; XING, A.; STASWICK, P.; CLEMENTE, T.E. The use of glufosinate as a selective agent in Agrobacteriummediated transformation of soybean. Plant Cell, Tissue and Organ Culture, v.56, p.37-46, 1999.

ZHU, Q.; DROGE-LASER, W.; DIXON, R.A.; LAMB, C. Transcriptional activation of plant defense genes. Current Opinion in Genetics \& Development, v.6, p.624-630, 1999.

ZIMMERMAN, J.L. Somatic embryogenesis: a model for early development in higher plants. The Plant Cell, v.5, p.1411$1423,1993$.

Received August 03, 2006

Accepted September 18, 2007 